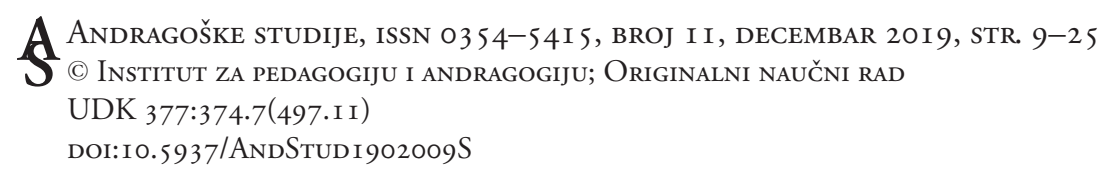

Monika Staab ${ }^{1}$

Julius-Maximilians-Universität Würzburg, Germany

\title{
Professional Self-Concept of Adult Education Staff in Serbia-Findings of a Qualitative Research Study
}

\begin{abstract}
Researching on the professional self-concept of adult education staff enables reflection on the professionalization of adult education on an individual level. A qualitative research study examines different professional biographies and identities of staff working in adult education in Serbia. The research creates a link between the professional careers of the interviewed staff and the professionalization structures, which are put forward by the Law on Adult Education. The results indicate that the professional self-concept is influenced by various factors on the societal, political, institutional and individual level. The aspect of education and training is highlighted.
\end{abstract}

Keywords: professionalization, professional self-concept, adult education

\section{Professionalization in the field of adult education}

Serbia is facing various political, economic and societal problems that have put the promotion of adult education on the national agenda. These include demographic and educational disparities (Statistical Office of the Republic of Serbia, 2014 ) and an unsteady unemployment rate-equaling to $12.1 \%$ in the first quarter of 2019, according to the latest data (TRADING ECONOMICS, 2019). Especially since the collapse of Yugoslavia at the end of 1990s, the idealistic orientation of adult education has changed (Medić, 2010). Adult education is seen as an effective instrument to face national problems. The Law on Adult Education passed in 2013 officially laid down the new mission of adult education in Serbia: employability, poverty reduction, socioeconomic growth and the improvement of quality of life are the main strategic goals (Law on Adult Education, 2013, Art.

\footnotetext{
${ }^{1}$ Monika Staab, M.A. is research assistant at the Professorship for Adult and Continuing Education within
} Julius-Maximilians-Universität Würzburg, Germany (monika.staab@uni-wuerzburg.de). 
4). Besides the structural and content-related changes, attention is paid to the professional development of staff working in the field of adult education. For the first time, the so far neglected vocational and continuing education of personnel in the education system was emphasized in the Law on the Fundamentals of the Education System in 2003. Subsequently, the Strategy of Adult Education Development in the Republic of Serbia (2006) focused on the development of education and training standards for teaching staff in adult education. It aims to improve the delivery and quality of the field. Afterwards, the Law on Adult Education has increased the focus on the qualification and tasks of staff working in the field of adult education. Kleisz (2013) outlines that professionalization is mainly put forward by political forces in former socialist countries. On the contrary, professionalization is mainly shaped by professional associations in liberal countries (p. 418).

At the same time, several EU strategies (e.g. Memorandum of Lifelong Learning, Adult Learning: It is never too late to learn, Action Plan on Adult Learning: It is always a good time to learn) were passed to support staff in adult education. The policy-based efforts are of strategic nature and focus on overarching goals, such as "Improving the quality and efficiency of education and training" (European Union, 2009). The policy level is supported by research activities, which focus on the definition of sets of skills and competences for adult educators (Bernhardsson \& Lattke, 2011; Buiskool, Broek, van Lakerveld, Zarifis, \& Osborne, 2010).

In the disciplinary discourse, a growing research interest on the professional development of adult educators can be identified. The "academic-view" (Lattke, 2016) includes various perspectives on the topic. Research activities range from the sociological dimension of the profession to the process of professionalization and its manifestation - the professionalism of adult educators, which emphasizes a philosophical and ethical dimension (Ovesni, 2018, p. 21).

Recognizing past efforts to support professionalization in adult education, present research focuses on a deeper understanding of professionalization on an individual level. The qualitative research study, which was conducted in the context of a master thesis in 2017, observes the professional self-concept of staff working in the field of adult education in Serbia. Based on six interviews, the professional biography and self-concept of employees who are working in different areas and institutions in adult education in Serbia are researched. The research is focused on the question: What is the professional self-concept of adult education staff in Serbia?

The collected data is analyzed in accordance with the qualitative content analysis by Mayring (2015). First, the interviews are analyzed on a case-by-case 
basis. Afterwards, the six cases are compared to identify similarities and differences in the professional self-concept of the interviewed staff. The findings provide an insight in adult education practice and disclose professional structures in the field. This enables critical reflection on the past efforts to support professionalization in adult education in Serbia.

The article summarizes the key findings of the described qualitative research study, focusing on the compared cases. In the first step, the paper outlines the past efforts on a political level to improve the professional development of adult education staff in Serbia. The paragraph reflects on the professionalization of adult educators in Serbia by examining the political dimension. In the second step, the article analyses the professional self-concept theoretically. The author relates mainly to German research in the field, without setting aside relevant research from the Serbian and international context. The German perspective on the topic is due to the origin of the author. Subsequently, the methodological approach is explained before the key findings of the study are presented, summarized and critically discussed.

\section{Professionalization of adult educators in Serbia}

Adult education as an academic discipline has a long tradition in Serbia. The Faculty of Philosophy at the University of Belgrade has been offering Andragogy as a study field since 1979 (Pejatović, 2016, p. 366). As for the occupational field, Serbia included the occupation of an andragogue in the National Vocational Qualification list in 1990 (Pejatović, 2016, p. 369). Despite this, the national report of CONFINTEA VI outlines the low public recognition and poor working conditions of adult education staff in Serbia (Medić, Popović, \& Milanović, 2009 , p. $33 \mathrm{ff}$.). Over the last two decades, several policies and educational strategies have prioritized the professional development of staff working in the field of adult education. The strategies aim at the improvement of education and training standards. Notably, the Law on Adult Education, which was enforced on January 1, 2014, has contributed to the ongoing professionalization in the field. The law defines job profiles with corresponding tasks. It restricts entryways into the job and formulates the standards of competence. Three job profiles can be differentiated: a) professional associate or andragogue (Art. 50), b) associate (Art. 51) and c) pedagogical and andragogical assistant (Art. 52).

a) The professional associate or andragogue obtains his/her job position through a degree course in Andragogy and is qualified to develop training and educational programmes, conduct evaluation, monitor- 
ing and research activities. The profession of andragogue was officially recognized in the national nomenclature of occupations in 1990. The professional associate is considered the best-qualified actor in the field of adult education in Serbia (Pejatović, 2016, p. 366-369).

b) People who studied adult education or completed vocational training in the field of adult education can also work as associates. Associates work in primary or secondary schools and in adult education institutions that have obtained the status of a publicly recognized activity organizer (PRAO). The status is awarded by the Institute for the Improvement of Education. It examines the educational programmes, personnel, premises, equipment and learning materials of the institution (Law on Adult Education, 2013, Article 17 \& 18). The Rulebook on precise conditions regarding the program, staff, space, equipment and teaching aids for obtaining the status of a publicly recognized adult education activity organizer (2015) defines the working requirements of the engaged staff. If a person cannot prove the professional skills for working with adults, he/she may attend eight training cycles at the Institute for Pedagogy and Andragogy of the Faculty of Philosophy at the University of Belgrade. After the completion of seven out of eight training cycles, the person will be able to work in a PRAO institution. The Serbian Association of Andragogists certifies the acquired competences for working in the adult education practice (Pejatović, 2016, p. 371f.).

c) The job of an andragogical assistant can be conducted by an adult educator, teacher or person who has completed a certain training program for becoming a pedagogical and andragogical assistant. The andragogical assistant is working in the field of Functional Elementary Adult Education (FEEA). He or she helps adults to complete their elementary school education (Pejatović, 2016, p. 369ff.).

The distinction between the three job profiles indicates a different level of knowledge, competences and attitudes of adult educators. The predefined professional pathways target different working fields in adult education practice. One can assume that different educational and professional pathways lead to differences in the professional performance. Ovesni (2009) detected in a study on the profession and professionalization of andragogues that andragogues who have obtained professional knowledge through formal university education demonstrate a greater professional behavior than employees who were inadequately prepared. By regulating the professional qualifications, job profiles, entryways and continuous training activities, the Law on Adult Education implements professional standards and regulations on the education and training of adult educa- 
tion staff to improve the professional practice. In a study on the social control of adult educators in Serbia, Ovesni (2010) "especially emphasized the importance of the existence and applications of professional standards" (p. 166) for professionalization on an individual level. After the implementation of the Law on Adult Education in 2014, it remains unclear how the standards and regulations have influenced the professional development and professional performance of staff working in the field of adult education in Serbia. In 2016, Pejatović (2016) identified weaknesses in (public) recognition, continuing training activities and in particular in the implementation of the legal status of a publicly recognized activity organizer (PRAO). Researching on the professional self-concept of adult education staff can disclose how the legal requirements have affected the professionalization of the individuals.

\section{The professional self-concept}

The professionalization of adult educators is a frequently discussed and researched issue in the field of adult and continuing education (Lattke, 2016). In the professionalization discourse, different theoretical approaches are discussed-going from the traditional perspective (Freidson, 2001) to the theories of a new professionalism (Evetts, 2011; Noordegraaf, 2007). Professions are understood as privileged occupational groups, which relate to a certain societal problem and a specific field of knowledge in the society. They work autonomously and have authority within their subject (Mieg, 2016, p. 29). In the traditional understanding, Freidson (2001) describes professions as third logic besides occupational groups, which are oriented towards the market logic and the logic of bureaucracy. Professions relate to a clearly defined area of knowledge and competences and are oriented towards specific values, which are part of a common professional ideology. Professions are self-regulated and autonomous. For instance, professional associations regulate entryways into the job, control the area of work and define continuing training programmes (p. 180). However, approaches of a new professionalism highlight that organizations and individuals have an important impact on professions. As professions are in constant development, the professionalization process has become the center of attention (Evetts, 2011; Noordegraaf, 2007). In the field of adult and continuing education, researchers argue that professionalization in adult and continuing education is influenced by employees, organizations and society equally (Egetenmeyer, Breitschwerdt, \& Lechner, 2018). Therefore, individual, organizational and societal factors need to be considered when researching on the professionalization of adult education. 
On an individual level, professionalization is understood as the process of turning general activities into occupational work that is oriented towards specific standards and values (Mieg, 2016, p. 30). Professionalization aims at the manifestation of professionalism. In the field of adult and continuing education, professionalism is defined as a reflexive and conscious activity where disciplinary and interdisciplinary knowledge is applied to deal with the particular situation in practice (Gieseke, 2010; Nittel, 2000). Professionalism results from the professional attitude and the specific knowledge and skills that are negotiated with the different needs of the target group and expectations of society (Fuchs, 2011; Peters, 2009). It is not a status that can be achieved, but an ongoing development process throughout the professional career (Fuchs, 2011, p. 111). The professional work of adult educators is an indicator for the quality of the whole field (Sava, 2011, p. 9f.).

The term "professional self-concept" focuses on the different aspects of professionalism and comprises one's own perception of skills and values in regard to the profession. The professional self-concept evolves in interaction with the tasks and expectations at the work place, and with one's own motives and perceptions (Schiersmann \& Eckert, 1990, p. 30f.). It is not static but develops over time. It influences the professional action and professional identity of the individuals as well, as it forms the public image of the profession (Fuchs, 2011, p. 39). As research activities focusing on the professional self-concept remain marginal, there is no precise definition on the professional self-concept. Referring to the presented professionalization theories, the following indicators compile different aspects, which concern the professional self-concept.

1. Field of work and job profile: Specific tasks, work place (organization), occupational biography, access to the job.

2. Education and continuing training: Acquiring and transferring relevant knowledge and skills.

3. Condition and challenges: Institutional, political and societal influences on the job.

4. Professional identity: Personal identity, ethical attitude.

Individual statements that relate to the four indicators reveal altogether the professional self-concept of a person. Based on the individual statements the strength of the reference to adult education discipline can be analyzed. Therefore, the individual statements can be analyzed on three axes, which are developed by Hartig (2009). On the first axis, the statements can be differentiated between people talking about their work in a personal manner and people referring in their statements to professional reasons and subject-specific content. The second 
axis differentiates between the inner direction of the individuals working in the field. On one side, people relate in their statements to socio-political topics and value adult education as an important instrument to achieve individual and societal goals. On the other side, people engage in the job because of technical reasons, e.g. they have the right knowledge and skills to do the job. In between these two manifestations, people align their work towards the interest and needs of participants, pursue societal objectives and refer in their descriptions specifically to adult education as a discipline. The third axis analyzes the level of abstraction in the language. The range goes from very narrow and task-related descriptions to very broad statements. Based on this analysis, personal and technical oriented statements indicate a low professional self-concept. People who refer specifically to adult education as a discipline and focus their work towards socio-political objectives or towards the target group, have a higher professional self-concept. Latter distance themselves from the work of the former, which seems to be performed without specific knowledge and skills. Statements which are abstract and based on the principles of the discipline increase the distinction between adult education and other professions.

Researching on the professional self-concept of adult educators on a national and international level, no common professional identity of adult educators can be identified (Alibabić \& Ovesni, 2006; Bron \& Jarvis, 2008; Fuchs, 2011; Hartig, 2009; Kraft, Seitter \& Kollewe, 2009). In fact, the field of adult and continuing education, including public recognition, aims, target group, etc., varies greatly on a national and international level (Despotović, 2010). However, a distinct professional self-concept is a prerequisite for the successful professionalization on a societal and individual level (Hartig, 2009, p. 206). Consequently, researching on the professional self-concept can provide insight into the current state of adult education practice and allows reflection on the professionalization in the field. In the continuation of the text, the professional self-concept of the interviewed staff is compared considering the legally predefined job profiles of adult education staff in Serbia. The research refers to the presented indicators and three axes, which serve as an analyzing tool.

\section{Methodology}

The following results are based on the collected data of a qualitative research study of 2017. In the context of a three-month Erasmus+ stay at the University of Belgrade, the author conducted six interviews with people working in the field adult education in Serbia. The sample was formed in a way that the interviewed 
staff is involved in different professional careers. The interviewees were selected according to the three defined job profiles and entryways regulated by the Law on Adult Education: 1. Professional Associate, entering the job on the basis of a completed university study; 2 . Andragogical Assistant, entering the job on the basis of a completed training course; 3 . Staff working in an organization recognized under PRAO, entering the job on the basis of a completed development program. The sample is as follows:

1. Andragogue A, female, 40-50 years, Institution related to regional and economic development and entrepreneurship.

2. Andragogue B, female, 50-60 years, People's workers and open university.

3. Andragogue C, female, 30-40 years, Adult elementary school and secondary school as adult education provider.

4. Andragogical Assistant A, male, 50-60 years, Secondary school as adult education provider.

5. Trainer A, male, 50-60 years, Secondary school as adult education provider.

6. Trainer B, female, 40-50 years, Scientific and specialized institution.

With each participant, a semi-structured interview was conducted in the English language. In four interviews, university staff translated between Serbian and English. During the translation process misinterpretation or wrong translation could have possibly occurred. Certain statements are re-phrased in the third person. Therefore, it is important to accept the presented findings of the study with reservation. The interviews are audio recorded, transcribed and anonymized. The data is analyzed in accordance with Mayring's (2015) qualitative content analysis. Each interview forms an individual case that is analyzed in two steps. In the first step, the data is examined along the four indicators: 1. Field of work and job profile, 2. Education and continuing training, 3. Condition and challenges, 4. Professional identity, that map the professional self-concept. In the second step, the statements are located on the three axes by Hartig (2009). The two-step approach generates a richer understanding of the professional self-concept and exposes how the individuals relate to adult education as a discipline. The six case studies are compared among each other. The comparison highlights similarities and differences in the professional self-concept of adult educators in Serbia. It discloses influencing factors on the professionalization of the interviewees and pictures the current state of professionalization on an individual level. Due to the rather small number of interviews, the results do not claim full completeness. In the continuation of the text, the author presents the results of the comparison. 


\section{Key findings of the study}

The key findings focus on the fields of work and job profiles, education and training, conditions and challenges at the work place, professional identity and strength of the professional self-concept regarding adult education.

\section{Field of work and job profile}

In relation to the field of work and job profile, the six case studies illustrate the broad and heterogeneous field of adult education in Serbia. The interviewees work in institutions that differ in structure and individual activities. Their educational and professional biographies relate to their job profile. For example, it can be noticed that a completed university degree leads to a higher occupational status, whereby previous working experiences also play an important role for entering a job. People, who have a study degree in Andragogy, usually fill leading positions and work in areas of educational policies, leadership and management. Individuals without academic background are more likely to work in counselling and teaching positions.

"Yes, the foundation was andragogy but also based on former education, the experiences that she gained previously in other positions, of course, made it possible to function as a director and to be a director of an institution." (Andragogue B, 1. 374-376)

\section{Education and continuing training}

Looking at the required knowledge and competences for the job, adult educators with a higher level of education link their answers to a higher extent to scientific knowledge in adult education and related disciplines (e.g. psychology). Practical and reflective knowledge is highlighted by personnel without academic background. The required competences vary along the different job positions and are primarily developed through informal learning settings. Among the six interviewees, communication skills are recognized as the most important. Knowledge about the discipline is transmitted through academic study programmes as well as formal vocational and continuing training programmes that are mainly conducted by the ministry and formal institutions of adult education. Learning which happens informally through personal experience and interpersonal contact is adding to it to a high degree. Employees who entered adult education 
without an andragogical background highlight the importance of formal training programmes, besides informal learning settings. The trainings impart relevant knowledge and competences for the job.

"So, this first awful training he delivered was with ten totally different adults and some of them were from different social categories, some social issues and so on, and he didn't have a problem with that educational part but to work with them. So, this was the reason why he felt he needed these trainings how to work with them." (Trainer A, 1. 562-565)

\section{Conditions and challenges}

Focusing on the conditions and challenges at the work place, it can be highlighted that societal, organizational and individual challenges greatly influence the individual job performance. The interviewed staff emphasize multiple weak points on a societal level in relation to the work place, e.g. educational disparities, illiteracy and the discrimination of Roma people. One interviewee outlines the problem of corruption:

"Every time we have elections there are people coming into these parts of the city and throughout Serbia and they are bringing presents, they are bringing food or sugar and oil and everything and the people are going to vote for them because of this. But when a person finished elementary school, it is less probable that he will do it like this and it is more probable that he will think for himself." (Trainer A, 1. 799-803)

Financial problems, the lack of qualified staff and problems in dealing with the target group are mentioned in relation to the institutions. Individual challenges are emphasized regarding the job profile, the institution and the professional biography. For instance, the deputy director of an institution concerned with regional and economic development and entrepreneurship, complains about the heavy workload. The staff without completed andragogical studies experience financial difficulties.

The job performance of the interviewees is influenced significantly by legal guidelines and regulations in the educational system as well as in the field of adult education, e.g. by the Law on Adult Education.

"You have special seminars. You cannot go to any seminar. It has to be approved by the government in order to get points so you can 
stay on your job. You need to get some points for professional development in order to stay, so you have to choose seminars approved by the government and there are these seminars." (Andragogical Assistant A, 1. 475-478)

Cooperation and networks are also an important factor. Cooperation inside the institution or outside with other organizations and partners are in most cases a necessity, which can be supportive or disruptive at the same time. In all cases, evaluation and monitoring activities are in place in order to control the job performance of the employees and/or the performance of the whole institution.

\section{Professional identity}

The professional identity of the interviewed staff is formed by societal challenges and the social function of adult education. All interviewees recognize the need and importance of adult education and lifelong learning in Serbia. They attribute adult education the competence of minimizing functional illiteracy and improving the living conditions in the Serbian society.

"Yes, and therefore adult education at this time is very important for Serbia because of that high percentage of, let us say, functionally illiterate people." (Andragogue B, 1. 594-595)

The professional role of the interviewees develops in relation to the societal function of adult education, the organizational orientation and the individual tasks. The personal value is related to the personal satisfaction of the individual. In addition, the interviewees highlight that a visible contribution is important. This contribution can be made in relation to their institution, to the society or towards the target group.

"And at the end of the training, at the end of the story, you see that you succeeded to do something and this is his personal satisfaction." (Trainer A, 1. 1062-1063)

\section{Reference to adult education}

Ranking the individual statements along the three axes introduced by Hartig (2009), the data shows that entering adult education through a university study program leads to a greater professional self-concept. Personnel entering adult education without an academic background use more personal oriented state- 
ments than others. However, all interviewees orient their work mainly towards the learning of adults. Adult education is often linked to a social mission.

"Our education does not end with formal education, there is permanent education. [...] Yes, for those who are andragogues that's a lifestyle." (Andragogue B, 1. 352-355).

In three cases, a stronger link to societal goals indicates the missionary character of the personnel. The professional attitude of the staff is clearly oriented towards the target group and the societal mission of adult education. The selfdescriptions are rather specific and task-related than abstract and related to adult education as a profession.

\section{Discussion}

By analyzing the main results of the research study, adult education in Serbia cannot be understood as a profession in the traditional understanding of Freidson (2001). The interviews do not indicate a common field of knowledge and competences. Although there are overlaps and accumulations in the answers, the stated areas of knowledge and competences depend on the educational and professional biography as well as the specific field of work. The orientation and performance of the job is not regulated by the profession itself and occupational associations are hardly mentioned. Instead, legal requirements and in particular the Law on Adult Education regulate the entryways, define the job profiles and state the mission of adult education in Serbia

Since the beginning of 2000, there have been efforts on improving adult education practice in Serbia. During the course of the interviews, it was visible that the implemented policies have a great impact on the staff working in the field of adult education. Educational activities are planned and organized in line with the legal requirements, both on an individual and institutional level. The Law on Adult Education, which regulates the entry into adult education practice, leads to differences in job profiles, qualifications and hierarchical positions. However, there is no clear distinction between the three job profiles. The results present consistent heterogeneity in the field of work, among the institutions and in the educational and professional biographies. Due to the ongoing changes in the legal regulations, the interviewed persons mention the need to update their knowledge on a regular basis. In one interview, it is criticized that the legal requirements do not consider the actual needs of the practitioners. This is obvious when looking at the diverse working fields and job profiles. Moreover, two inter- 
viewees mention that the required continuing training activities are still rare and staff cannot attend trainings regularly. However, staff value the education and training opportunities as essential for their professional practice.

The importance of education and training is also emphasized when analyzing the self-descriptions along the three axes. The staff who completed an academic study in Andragogy refer to adult education as a discipline to a greater extent than the staff who entered their job without an andragogical study degree. Subsequent formal, non-formal and informal education and training activities are increasing the reference to adult education. The results outline that personnel who attended only a few formal and non-formal training courses refer the least to knowledge, competences and topics in adult education. Consequently, education and continuing training have a great impact on the professionalization of personnel in adult education.

Besides the legal regulations and standards, the interviewees mention that requirements and expectations of the institutions, as well as networking and cooperation, have an impact on the job performance. The key findings indicate that adult education staff are influenced by the organizations as well as legal requirements. The interviewed staff direct their work towards societal needs and needs of the target group. Summing up, the professionalization of staff in the field of adult education is closely connected to different organizational, political and societal factors. It suggests a multilevel perspective on the individual professionalization that goes beyond "a limited perspective on the personnel (e.g. its qualification, salary and individual or collective performance)" (Egetenmeyer et. al., 2019, p. 14). This is why the professional self-concept of adult education staff constitutes a complex and individual construct that is in constant development. Regarding the six interviewed staff working in adult education in Serbia, the orientation towards adult education as a discipline varies along the individual educational and professional biographies and the specific fields of work.

\section{Conclusion}

The professional self-concept of staff has an impact on the professional identity and professional performance of the individuals, as well as on the public image of the field (Fuchs, 2011, p. 39). Research which is focused on the professional self-concept can disclose adult education practice and presents the current state of professionalization on an individual and organizational level. As professionalization in adult education is more and more discussed under a multi-level perspective (Egetenmeyer et. al., 2019) and argued under approaches of a new professional- 
ism (Evetts, 2011;Noordegraaf, 2007), professions should avert their privileges and autonomous structures. Instead, professionalization should orient towards the actual needs and requirements of the work place (Kleisz, 2013, p. 417-418).

"This is not as much about being a professional as it is about becoming professional in modern times, or more precisely, about showing that one is becoming professional without necessarily ever becoming one." (Noordegraaf, 2007, p. 775)

As the professional self-concept is strongly connected with the education and training of the individual, there is need for ongoing and adequate education and training activities. Beside the formal and non-formal learning settings, which are highlighted by the Law on Adult Education, informal learning settings play a significant role, too. Requiring knowledge and competences through informal learning must not be underestimated. Concluding, the professionalization of adult educators should be promoted to improve and assure the quality of the whole field. Educational policies can support this development by responding to the actual needs and requirements in adult education practice.

\section{References:}

Alibabić, S. \& Ovesni, K. (2006). Andragogic stimulation of the teacher professionalization. In N.P. Terzis (Eds.), Lifelong learning in the Balkans (pp. 499-507). Thessaloniki: Publishing House Kyriakidis Brothers S.A.

Bernhardsson, N. \& LatTKe, S. (2011). Core competencies of adult learning facilitators in Europe. Findings from a transnational Delphi Survey. Conducted by the project "Qualified to Teach". QF2TEACH partnership. Retrieved from http://asemlllhub. org/fileadmin/www.dpu.dk/ASEM/events/RN3/QF2TEACH_Transnational_ Report_final_1_.pdf

BRON, A. \& JaRvis, P. (2008). Identities of adult educators: Changes in professionality. In E. Nuissl \& S. Lattke (Eds.), Qualifying adult learning professionals in Europe (pp. 33-44). Bielefeld: wbv.

Buiskool, B. J., Broek, S. D., van Lakerveld, J. A., Zarifis, G. K., \& Osborne, M. (2010). Key competences for adult learning professionals. Contribution to the development of a reference framework of key competences for adult learning professionals. Final report. Zoetermeer: Research voor Beleid. Retrieved from http://conference. pascalobservatory.org/sites/default/files/keycomp_0.pdf

Despotović, M. (2010). Professionalization of adult education - between public and scientific (non) recognition. In S. Medić, R. Ebner \& K. Popović (Eds.), Adult education: The response to global crisis. Strengths and challenges of the profession (pp. 47-71). Serbia: Department of Pedagogy and Andragogy, Faculty of Philosophy, 
University of Belgrade. Serbia: Institute for Pedagogy and Andragogy, Faculty of Philosophy, University of Belgrade. Brussels: European Association for Education of Adults. Belgrade, Serbia: Adult Education Society.

Egetenmeyer, R., Breitschwerdt, L., \& Lechner, R. (2019). From 'traditional professions' to 'new professionalism': A multi-level perspective for analysing professionalization in adult and continuing education. Journal of Adult and Continuing Education, 25(1), 7-24. https://doi.org/10.1177/1477971418814009

European Union (2009). Notices from European Union institutions and bodies. Council conclusions of 12 May 2009 on a strategic framework for European cooperation in education and training ('ET 2020'). Brussels. Retrieved from https://www.cedefop. europa.eu/files/education_benchmarks_2020.pdf

Evetts, J. (2011). A new professionalism? Challenges and opportunities. Current Sociology, 59 (4), 406-422.

FLICK, U. (2007). Qualitative Sozialforschung. Eine Einführung. Reinbek bei Hamburg: Rowohlt Verlag.

Freidson, E. (2001). Professionalism: The third logic. Cambridge: Polity.

Fuchs, S. (2011). Professionalitätsentwicklung des Weiterbildungspersonals. Tätigkeiten, Kompetenzen und Fortbildung von Trainern in der beruflichen/betrieblichen Weiterbildung. Hamburg: Verlag Dr. Kovač.

Funr, T. (1991). Kompetenzen und Ausbildung des Erwachsenenbildners. Eine Studie zur Professionalisierung der Erwachsenenbildung. Bad/Heilbrunn/Obb.: Verlag Julius Klinkhardt.

Giesere, W. (2010). Professionalisierung in der Erwachsenenbildung/Weiterbildung. In R. Tippelt \& A. v. Hippel (Eds.), Handbuch Erwachsenenbildung/Weiterbildung (pp. 385-403) Wiesbaden: VS Verlag.

Hartig, C. (2009). Berufliche Selbstbeschreibung als berufskulturelle Selbstaufklärung. In W. Seitter (Eds.), Professionalitätsentwicklung in der Weiterbildung (pp. 205231). Wiesbaden: VS Verlag.

KLeIsZ, T. (2013). Quality in focus - Why professionalism isn't enough of a guarantee? Contemporary issues affecting the learning professions. In M. Despotović, E. Hebib \& B. Németh (Eds.), Contemporary issues of education quality (pp. 409-421). Serbia: Faculty of Philosophy, University of Belgrade; Institute for Pedagogy and Andragogy, University of Belgrade. Hungary: Faculty of Adult Education and HRD, University of Pécs.

Kraft, S., Seitter, W., \& Kollewe, L. (2009). Professionalistätsentwicklung des Weiterbildungspersonals. Bielefeld: W. Bertelsmann Verlag.

LATTKE (2016). Research on professionalization of adult educators. In S. Sava \& P. Novotný (Eds.), Researches in adult learning and education: the European dimension (pp. 85-99). Firenze: Firenze University Press.

Mayring, P. (2015). Qualitative Inhaltsanalyse. Grundlagen und Techniken (12, überarbeitete Auflage). Weinheim und Basel: Beltz Verlag.

Medić, S. (2010). Andragogical profession - Traps, controversies and perspectives. In S. Medić, R. Ebner \& K. Popović (Eds.), Adult education: The response to global 
crisis. Strengths and chalenges of the profession (pp. 31-45). Serbia: Department of Pedagogy and Andragogy, Faculty of Philosophy, University of Belgrade. Serbia: Institute for Pedagogy and Andragogy, Faculty of Philosophy, University of Belgrade. Brussels: European Association for Education of Adults. Belgrade, Serbia: Adult Education Society.

Medić, S., Popović, K. \& Milanović, M. (2009). National report on the development and state of the art of adult learning and education. Serbia. confintea VI - 6th international conference on adult education. Belgrade: Adult Education Society; Bonn: DVV International - Institute for International Cooperation of the German Adult Education Association; Sarajevo: SEE Regional Office.

Mieg, H.A. (2016). Profession: Begriff, Merkmale, gesellschaftliche Bedeutung. In M. Dick, W. Marotzki \& H. Mieg (Eds.), Handbuch Professionsentwicklung (pp. 2740). Bad Heilbrunn: Verlag Julius Klinkhardt.

Nittel, D. (2000). Von der Mission zur Profession? Stand und Perspektiven der Verberuflichung in der Erwachsenenbildung. Bielefeld: Bertelsmann (Theorie und Praxis der Erwachsenenbildung).

Noordegraaf, M. (2007). From "Pure" to "Hybrid" Professionalism. Present-Day Professionalism in Ambiguous Public Domains. Administration \& Society, 39 (6), $761-785$.

Ovesni, K. (2009). Andragoški kadrovi-profesija i profesionalizacija. Beograd: Institut za pedagogiju i andragogiju Filozofskog fakulteta.

Ovesni, K. (2010). Social control of adult educators in Serbia. In S. Medić, R. Ebner \& K. Popović (Eds.), Adult education: The response to global crisis. Strengths and chalenges of the profession (pp. 151-169). Serbia: Department of Pedagogy and Andragogy, Faculty of Philosophy, University of Belgrade. Serbia: Institute for Pedagogy and Andragogy, Faculty of Philosophy, University of Belgrade. Brussels: European Association for Education of Adults. Belgrade, Serbia: Adult Education Society.

Ovesni, K. (2018). Professionalization in the field of adult education and learning in the territory of former Yugoslavia, Andragoška spoznanja, 24(4), 19-36. DOI: http:// dx.doi.org/10.4312/as.24.4.19-36

Pejatović, A. (2014). Functional Elementary Adult Education in the Republic of Serbia - A new model for development of adult competencies, Journal of Educational Sciences, 2 (30), 40-51.

Pejatović, A. (2016). Professionalization in Serbian adult education - Toward the complementary model. In K. Tóth Fodorné (Eds.), Felsöoktatási kihivások. Al-kalmazkodásstratégiaipartnerségben. Challenges to higher education. Adaptation in strategic partnership (p. 364-374). Pécs: Tanulmánykötet.

Peters, R. (2004). Erwachsenenbildungs-Professionalität. Ansprüche und Realitäten. Bielefeld: W. Bertelsmann Verlag.

Sava, S. (2011). Towards the Professionalization of Adult Educators. Andragoškestudije, 2, 9-22. 
Schiersmann, C. \& Eckert, S. (1990). Wie Lehrende sich selbst verstehen - Aspekte der Rollen-interpretation. Tübingen: Deutsches Institut für Fernstudien an der Universität Tübingen.

Statistical Office of the Republic of Serbia (2014): 2011 Census Atlas. 2011 Census of Population, Households and Dwellings in the Republic of Serbia. Belgrade. Retrieved from https://publikacije.stat.gov.rs/G2014/PdfE/G20144012.pdf

Trading Economics (2019). Serbia Unemployment Rate. Retrieved from https://tradingeconomics.com/serbia/unemployment-rate

Monika Staab ${ }^{2}$

Univerzitet Julijus Maksimilijan u Vircburgu, Nemačka

\section{Profesionalni samokoncept zaposlenih u sferi obrazovanja odraslih u Srbiji - saznanja iz kvalitativne istraživačke studije}

Apstrakt: Istraživanje profesionalnog samokoncepta zaposlenih u sferi obrazovanja odraslih omogućava razmatranje profesionalizacije obrazovanja odraslih na individualnom nivou. U okviru ove kvalitativne istraživačke studije ispitane su različite profesionalne biografije i identiteti zaposlenih u sferi obrazovanja odraslih u Srbiji. Ovo istraživanje uspostavlja sponu između profesionalnih karijera intervjuisanih zaposlenih i struktura profesionalizacije koje su obuhvaćene Zakonom o obrazovanju odraslih. Rezultati ukazuju na to da na profesionalni samokoncept utiču različiti faktori na društvenom, političkom, institucionalnom i individualnom nivou. Ovo istraživanje ujedno ističe aspekt obrazovanja i obuke.

Ključne reči: profesionalizacija, profesionalni samokoncept, obrazovanje odraslih

\footnotetext{
2 Monika Staab, M.A., naučni je saradnik na Katedri za obrazovanje odraslih i kontinuirano obrazovanje pri Univerzitetu Julijus Maksimilijan u Vircburgu, Nemačka (monika.staab@uni-wuerzburg.de).
} 